\title{
Anatomy and stomatal micromorphology of Psophocarpus tetragonolobus (L.) DC. (Winged Bean)
}

\author{
Kamal Kumar. $\mathbf{V}^{1^{*}}$, Rajalakshmi $\mathbf{R}^{2}$ \\ ${ }^{1,2}$ Department of Botany, University of Kerala, Karyavattom, Thiruvananthapuram, Kerala, India-695581 \\ Corresponding Author: kamaldivakar@gmail.com
}

Available online at: www.isroset.org

Received: 29/Jan/2019, Accepted: 12/Feb/2019, Online: 28/Feb/2019

\begin{abstract}
Psophocarpus tetragonolobus (winged bean) belongs to the family Fabaceae. It is self-pollinated and growing in the tropical regions of the world. Present study investigated the anatomy of stem, node, petiole, leaf, root and stomatal micromorphological characters of this species. Stem anatomy showed epidermis, cortical layers (collenchyma and chlorenchyma) schlerencymatous bundle sheath with conjoint, collateral vascular bundle and unilacunar node. One of the distinguishing features in leaf anatomy was the presence of sac like outgrowths filled with simple parenchyma and were usually seen opposite side to the midrib vascular bundle. In the petiole, vascular strands were cylindrical and arc shaped and in roots, four xylem and four phloem patches were present. Paracytic stomata were seen on both sides of the leaves. The stomatal index on adaxial and abaxial surface was 5.54-9.27\% and 53.57-61.29\% respectively. In general anatomical characteristics of P.tetragonolobus were used for the identification key of this species.
\end{abstract}

Keywords- Psophocarpus tetragonolobus, stem, leaf, petiole, root, node, stomata, paracytic, adaxial, abaxial

\section{INTRODUCTION}

Psophocarpus tetragonolobus (L.) DC. (winged bean) is a twinning perennial herb belonging to the family Fabaceae, subfamily Papilionoideae commonly known as four-angled bean, Goa bean, short day asparagus pea and Manila bean. This plant is a promising legume growing in the tropical region of the world. It is predominantly self-pollinated, twinning habit, longitudinally winged pods with tuberous roots [1]. Every parts of winged bean (root, stem, leaves and flowers) are tasty and edible [2]. This plant has assumed considerable importance as a protein rich multipurpose legume [3-6]. Detailed taxonomy, genetic diversity and physiochemical analysis of winged bean were conducted by, Verdcourt et al. in 1978 [7], Khan in 1976 [8] and Chandra et al. in 2015 [9]. Yang et al. in 2018 [10] reported the origin and diversification of winged bean. KamalKumar and Rajalakshmi in 2018 [11] reported polyembryony in Psophocarpus tetragonolobus. However, the anatomical characterization of $P$. tetragonolobus has not been yet investigated. So the present study was conducted to provide a comprehensive anatomical description and the stomatal characteristics of P.tetragonolobus. Anatomical characteristics will be more valuable and useful in the description of the species. Furthermore anatomical features could be used in diagnostic key of taxa at all taxonomic levels.

\section{MATERIALS AND METHODS}

For the anatomical study, mature fresh roots, stems, leaves, nodes and petioles were selected and fixed in FAA solution. Manual cross sections were made from the base of stems and middle part of leaves and petioles. Sections were stained in aqueous $1 \%$ safranin for two minutes. The excess stain was washed away with distilled water and mounted in 50\% glycerin, sealed using wax and observed under a microscope (Olympus CH20i). Photomicrographs were taken using Image analyser (Leica DM2000). Some anatomical characters such as shape of vascular bundles, arrangement of vessels, number of epidermis layer and cortex in stem, outline shape of petiole and root cross section, number of epidermis layers, and shape of pith were analyzed.

For micro morphological study of stomata, mature leaves were collected. The leaves were chopped into $1 \mathrm{~cm}$ fragments and boiled with $80 \%$ alcohol for 30 minutes. The treated leaves were taken out from alcohol and again treated with $5 \%$ sodium hydroxide and incubated at $40^{\circ} \mathrm{C}$ overnight. The cleansed leaves were rinsed with distilled water. For final clearing, leaves were treated with $10 \%$ sodium hypochloride solution for 10 minutes. The lower and upper epidermal layers were removed, rinsed with distilled water, stained with $1 \%$ safranin for 2 minutes. Excess stain was washed with distilled water and mounted in $50 \%$ glycerin, sealed with glycerin and observed under a microscope (Olympus CH20i). Photomicrographs were taken using 
Image analyser (Leica DM2000). The frequency of stomata was calculated as number of stomata per $1 \mathrm{~cm}^{2}$ area under compound microscope (Olympus CH20i). The Stomatal Index was calculated using the standard formula [12] given below.

Where,

$$
S . I=\frac{S}{(S+E)} \times 100
$$

S.I= Stomatal Index

$\mathrm{S}=$ Number of stomata per unit area

$\mathrm{E}=$ Number of epidermal cell in unit area

\section{RESULTS AND DISCUSSION}

The present study provides valuable information about the anatomy of aerial parts and root of P.tetragonolobus. Metcalfe and Chalk in 1950 [13] explained the general anatomical characteristics of the family Fabaceae. However, the stem, root, petiole, leaf and nodal anatomy of P.tetragonolobus provided in the present study is the first report.

\section{Anatomy of stem}

Cross section of the stem (Figure 1) of P. tetragonolobus showed that the epidermis was more or less wavy in outline and composed of single layer of thick walled parenchyma cells with cuticle. Trichomes were absent in the epidermal cells. This layer was followed by broad cortical layers containing 5-6 collenchyma layers and 3-4 layers of chlorenchyma. The cortex was followed by 13-16 conjoint, collateral, open vascular bundles containing sclerenchymatous bundle cap and intrafascicular cambium. Xylem bundles were endarch in nature. Erythrina velutine (Fabaceae) also exhibited similar anatomical structure [14]. The pith in P.tertagonolobus was very broad and composed of simple parenchyma cells.

\section{Nodal anatomy of stem}

Compared to internodal anatomy of P.tetragonolobus, nodal region showed a very notable variation in both structure and composition of tissues. At initial stage of growth the nodal anatomy was almost similar to that of internodal region. But as the growth progress the nodal region showed some modifications in its anatomy.

At the initial stage, the cross section (Figure 2) of nodal region displayed irregular outline with a prominent $\mathrm{C}$-shaped bulging which indicates the development of leaf, bud, and auxiliary branch trace. The epidermis was single layered made up of thick walled parenchyma cells. It was followed by medium sized cortex containing 1-3 layers of collenchyma and 1-2 layers of chlorenchyma. This was followed by single layered parenchymatous endodermis and pericycle. In the $\mathrm{C}$-shaped bulged portion, the tissue arrangement was different and it included single layered thick walled parenchyma followed by 5-6 layered collenchyma cells. But chlorenchyma layer was not so developed or completely absent. During the initial stage Cshaped vascular bundles develops towards the pith region. It represents the development of bud trace which may later form as leaf bud trace, flower bud trace or auxiliary branch trace. The vascular bundles except in C-shaped bulged portion, showed as patches with a prominent sclerenchymatous bundle cap. It was followed by many layered phloem cells with prominent endarch xylem, seen as a complete ring. The broad pith made up of single large parenchyma cells. Another notable feature of $P$. tetragonolobus nodal part was that opposite to the bud trace the xylem was very large and giving branches of conducting tissues to the bud trace. This vascular bundle was very large compared to all other vascular bundles present in the nodal part. In this stage a single leaf gap and leaf trace were seen in nodal region. This confirmed the presence of unilacunar node in $P$. tetragonolobus stem.

In final stage (Figure 3) variation in tissue arrangement occurred from the origin primordia and branching trace. The epidermis was extended vigorously and form a heart shaped primodia with a wing like extension in its lower part. In region of primordia except in the winged portion single layered epidermis was observed. This was followed by many layered compactly arranged parenchymatous tissues having very prominent elongated xylem traces. The parenchymatous tissues found in the cortical portion near the branching traces were thick walled with some inclusions. The notable feature is the lower extended wing shaped region of primordia, the nodal stem was covered by single layered epidermis. At extreme ends of this extended wing shaped region chlorenchyma was seen as patches. A single thick walled vascular bundle trace was also be seen in the region where the extended wing shaped part of primordia met the nodal stem.

\section{Anatomy of Leaf}

C.S of leaf (Figure 4) of P. tertagonolobus showed unilayered upper and lower epidermis containing thick walled parenchyma cells with stomata distributed on both epidermis. This was followed by mesophyll cells containing upper unilayered chlorophyll containing palisade cells and lower spongy cells. Midrib vascular bundles were comparatively larger than other small vascular bundles in leaf. Each vascular bundle including the midrib bundle composed of sclerenchyma hypodermis, xylem and phloem. One of the distinguishing features in leaf anatomy of P.tertagonolobus was the presence of sac like outgrowths filled with simple parenchyma and were usually seen opposite side to the midrib vascular bundle. 
A

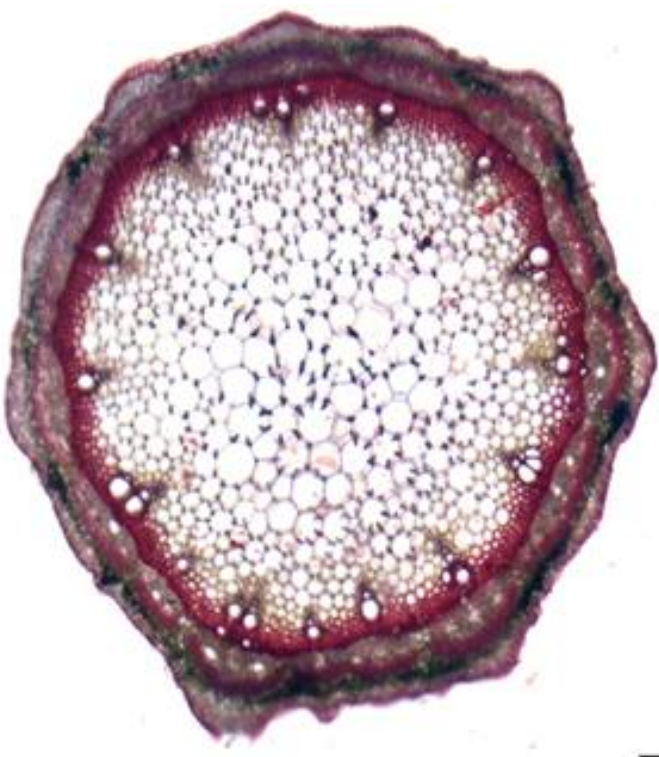

$100 \mathrm{jm}$

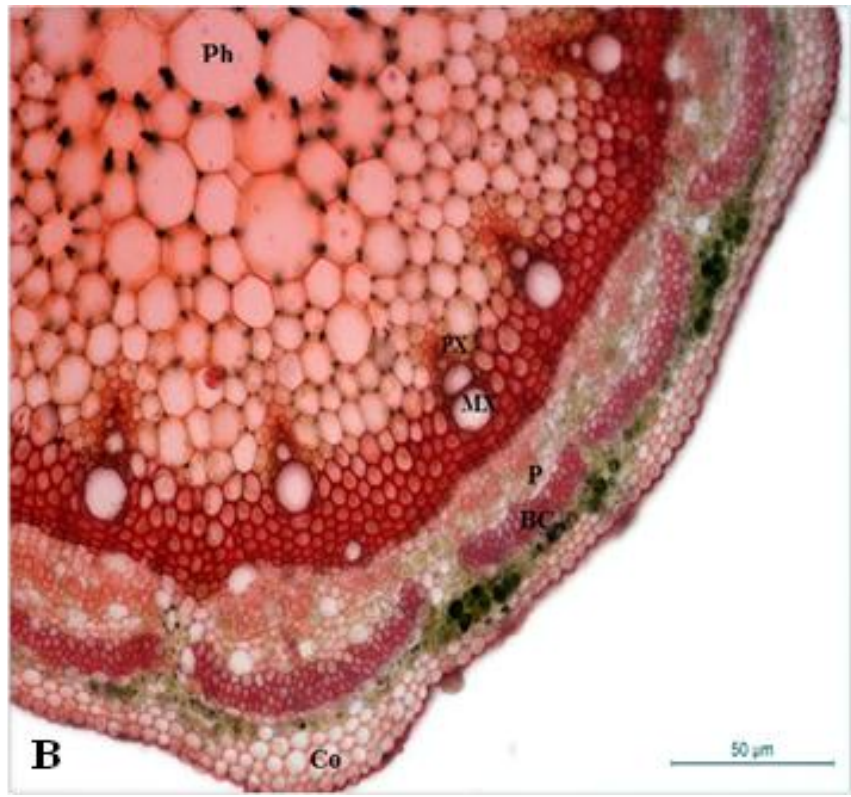

Figure 1. Stem of Psophocarpus tetragonolobus A) Ground Plan in cross section B) Cortex, Bundle cap, Phloem, Metaxylem, Protoxylem and Pith in cross section. Co-Cortex, BC-Bundle Cap, P-Phloem, MX-Metaxylem, PX-Protoxylem, Ph-Pith.
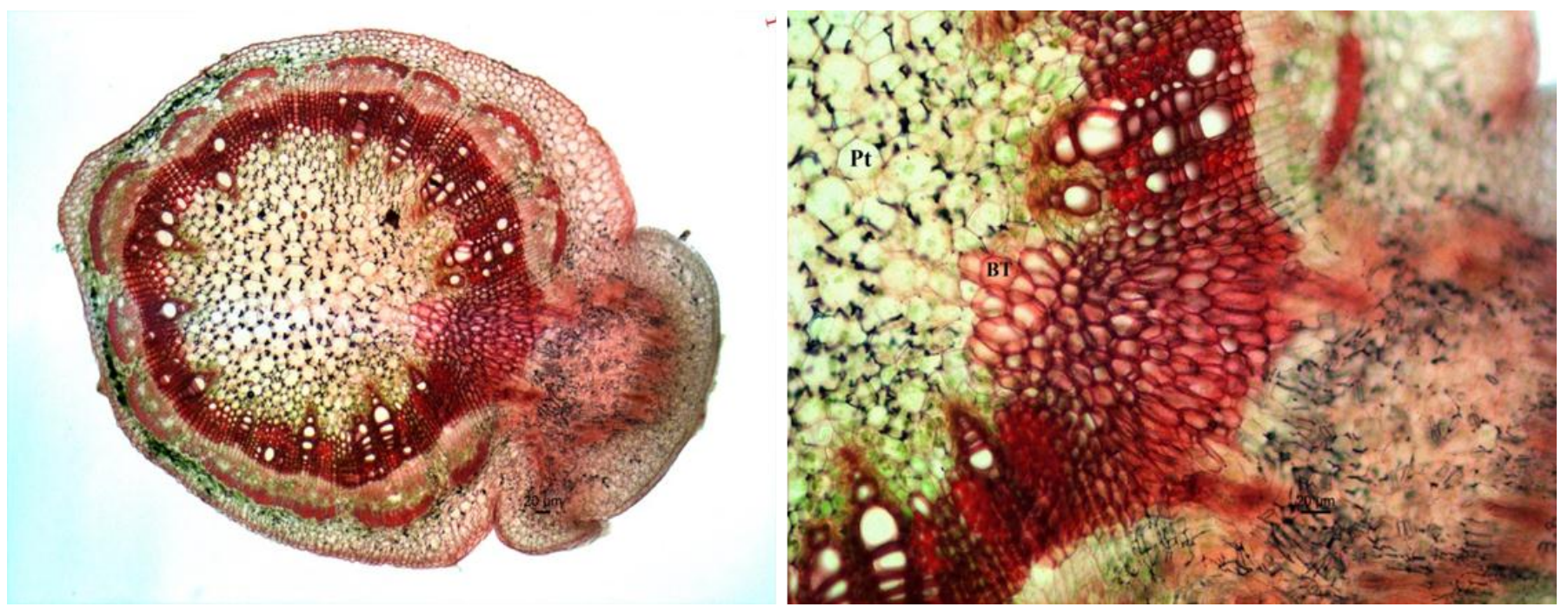

Figure 2. Nodal anatomy at initial stage of Psophocarpus tetragonolobus A) Ground plan in cross section B) Formation of single gap and single trace. BT-Bud trace, Pt-Pith. 

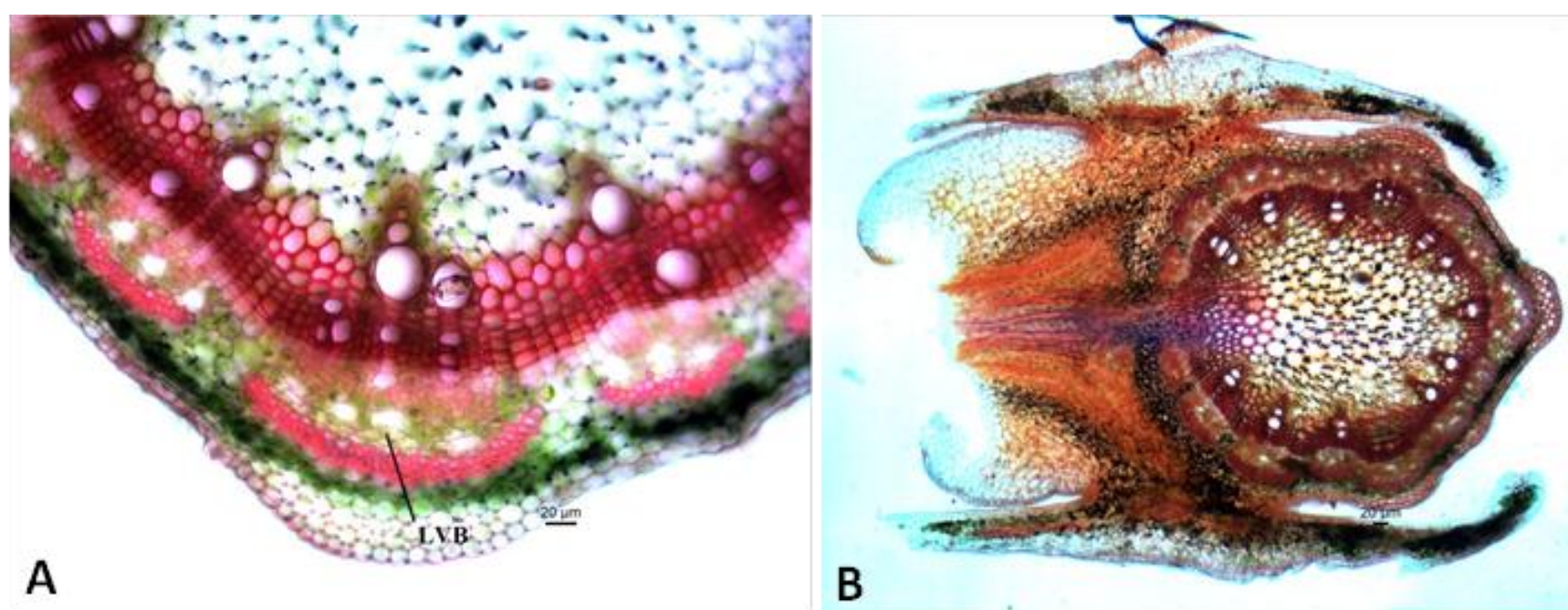

Figure 3. Nodal anatomy at final stage of Psophocarpus tetragonolobus A) Very large vascular bundle seen opposite to the leaf trace in cross section. B) Development of prominent primordia, LVB - Large vascular Bundle
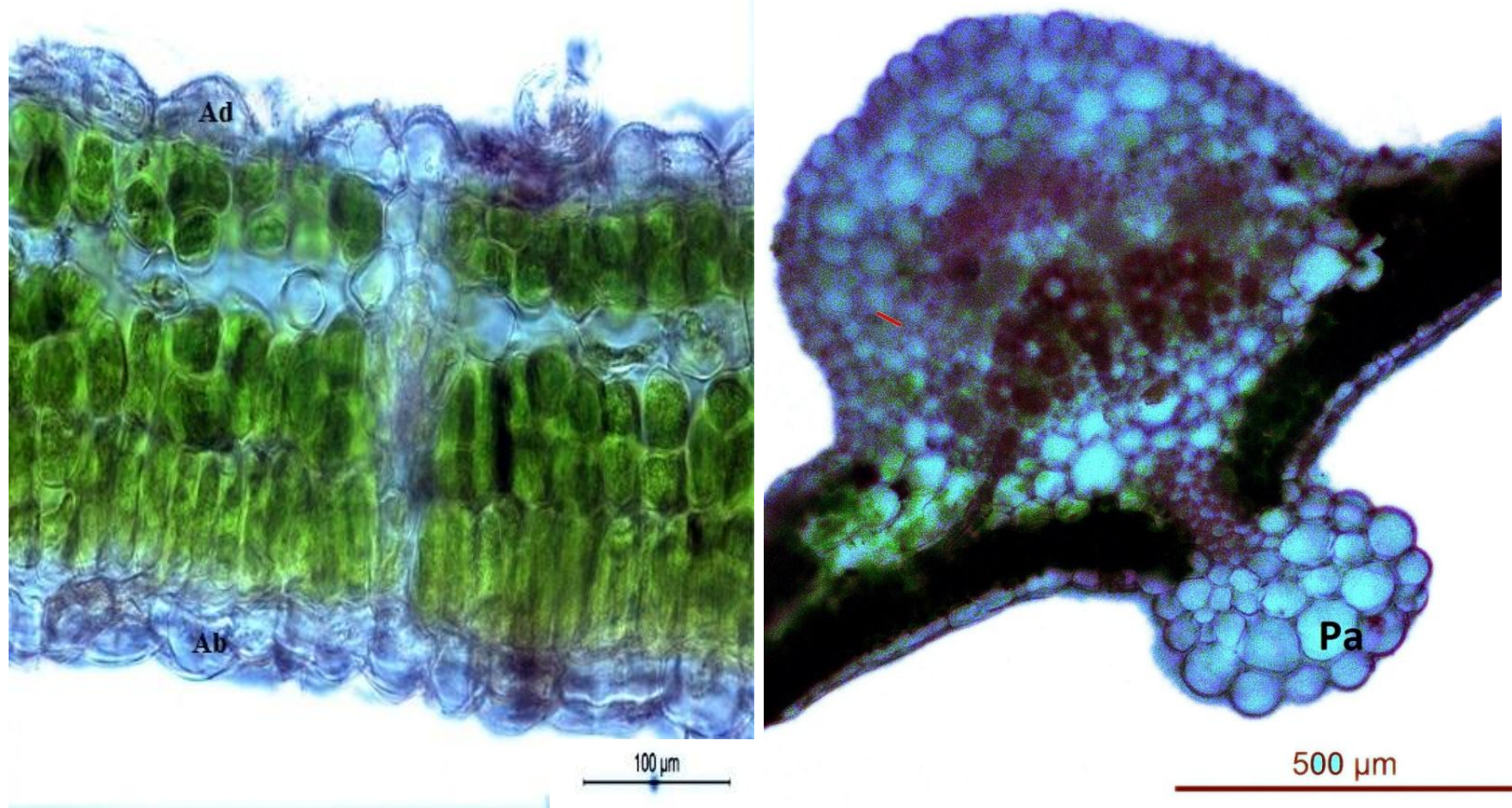

$500 \mu \mathrm{m}$

Figure 4. . Leaf of Psophocarpus tetragonolobus A) Adaxial, Abaxial and mesophill cells in cross section B) Parenchyma and vascular bundle in midrib region in cross section. Ad-Adaxial, Ab-Abaxial, P-Parenchyma 

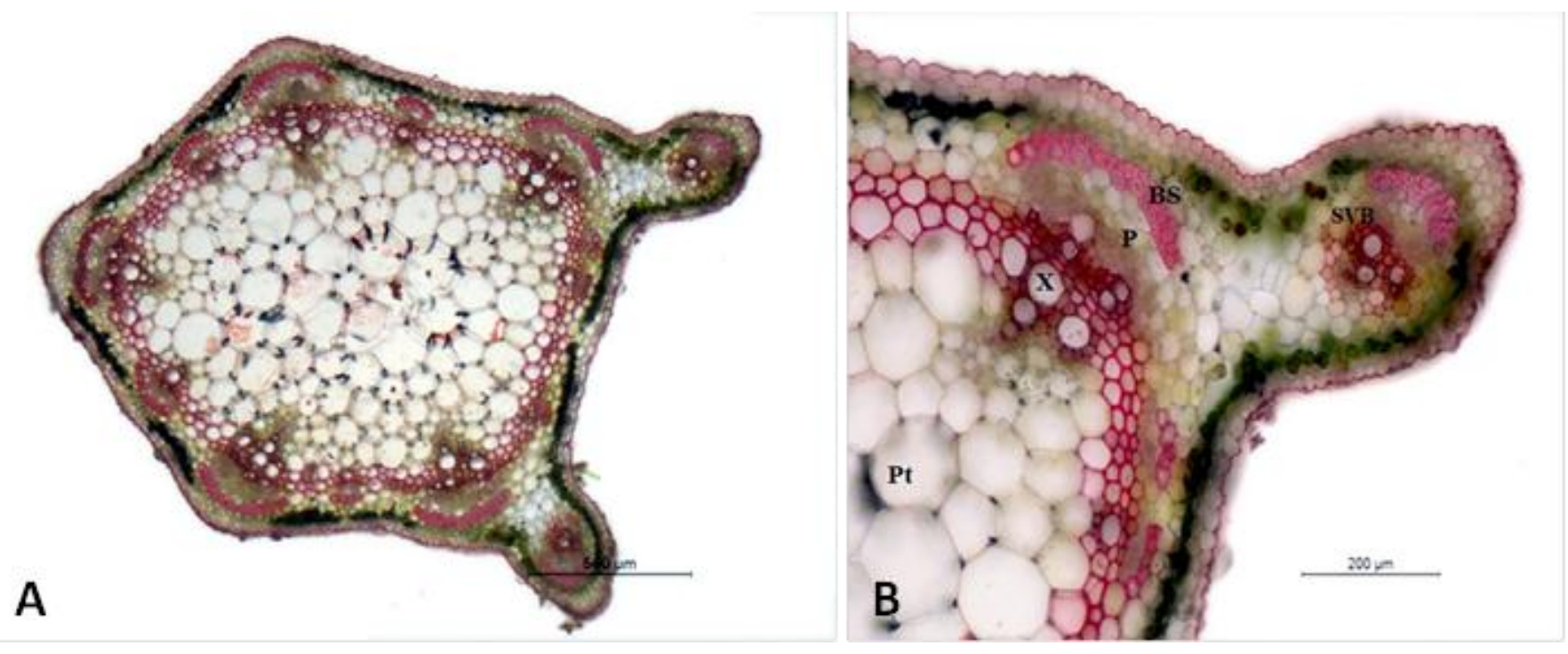

Figure 5. Petiole of Psophocarpus tetragonolobus. A) Cross section of petiole B) Small vascular Bundle, Bundle sheath, Phleom, Xylem and Pith in cross section. SVB-Small vascular bundle, BS-Bundle sheath, P-Phleom, X-Xylem, Pt-pith
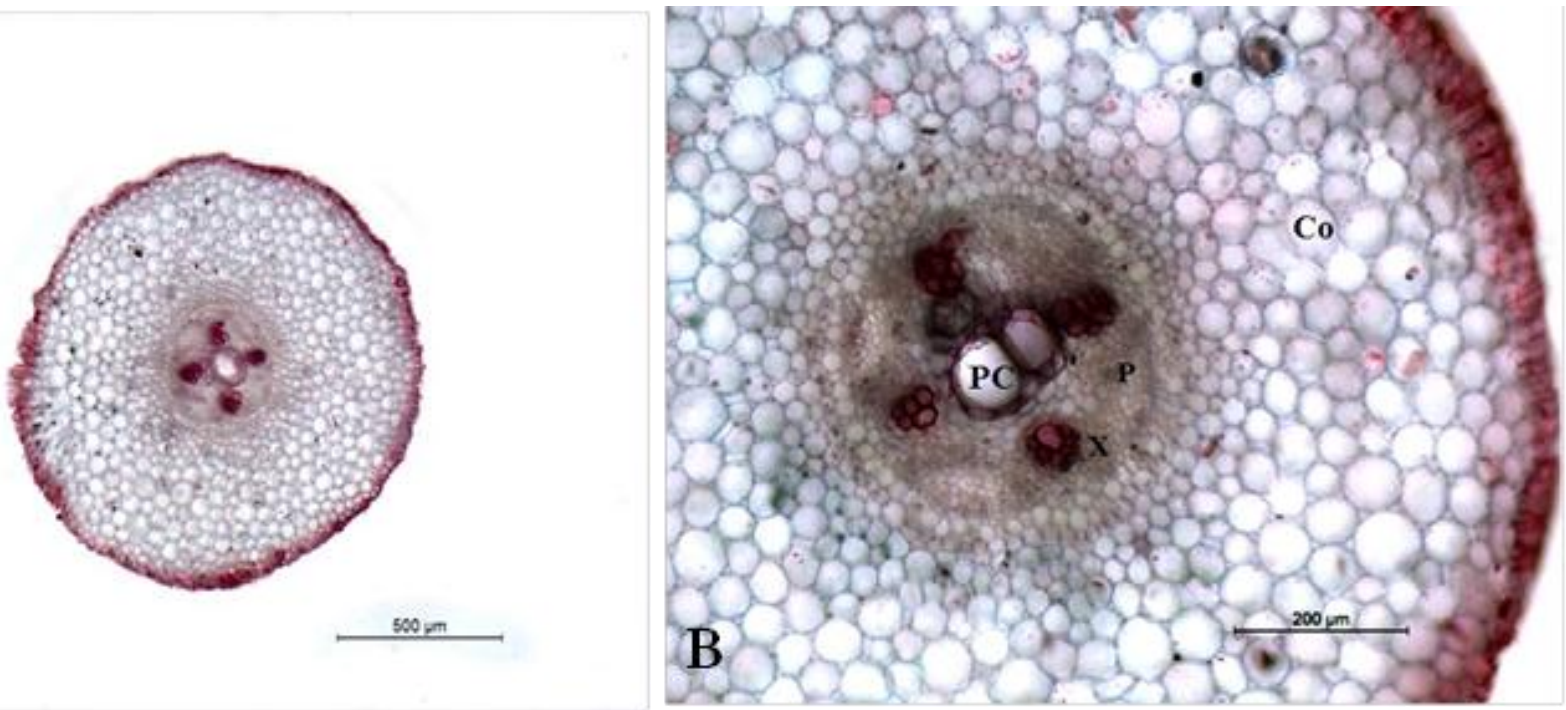

Figure 6. Root of Psophocarpus tetragonolobus A) Ground plan in cross section B) Cortex, Phleom, Xylem and Pith cavity in cross section. Co-Cortex, P-Phloem, X-Xylem, PC-Pith Cavity. 

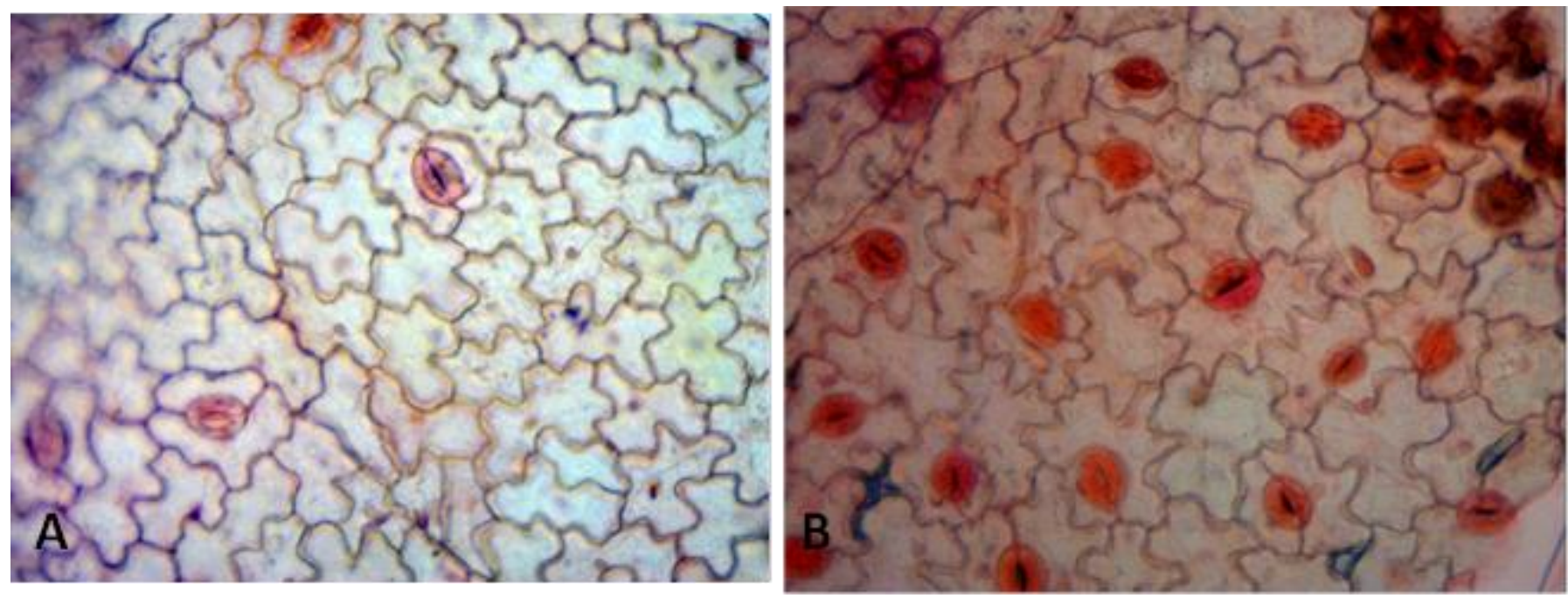

Figure 7. Stomata of Psophocarpus tetragonolobus A) Stomata in adaxial surface B) Stomata in abaxial surface

\section{Anatomy of Petiole}

C.S of petiole (Figure 5) of P.tetragonolobus showed single layer of outer thick walled parenchyma cells which was followed by two layers of parenchyma cells and one to two layers of chlorenchyma cells. This chlorenchyma cells were followed by 10 to 11 main vascular strands. These main vascular strands composed of separate bundles. Vascular bundles were cylindrical and arc shaped. These vascular systems were already reported in plant species of Crotalaria, Erythrina crista, Galega oficinalis, Glycine soja, Glycyrrhiza glabra, Halimodendron halodendron, Lathyrus maritimus, Lupinus mutabilis, Phaseolus multiflorus, Robinia pseudacacia, Wistaria floribunda and W.sinensis [13]. The petiole has another two small vascular bundles with large parenchyma pith. Schlerenchymatous bundle sheath was observed in vascular bundle. Vascular bundles consisted of xylem, phloem and cambium.

\section{Anatomy of root}

C.S of root (Figure 6) of P.tetragonolobus was more or less circular in outline having single layer of thick walled epiblema made up of paranchyma cells. Epiblema was followed by broad parenchymatous cortex. Endodermis and pericycle were made up of parenchyma cells. Xylem vessels were polygonal in shape and exarch condition. Four xylem patches and four phloem patches were arranged in radially. This kind of observation was reported in Stylosanthes hippocampoides and Lathyrus latifolius also [15]. Pith cavity was observed in the center of root.

\section{Micromorphological studies of stomata}

In P.tetragonolobus, stomata were found on both surfaces of leaves and already investigated in the species of Alysicarpus,
Arachis, Argyrolobium, Canavalia, Crotalaria, Dalbergia, Desmosium, Dolichos, Eriosema, Indigofera, Mucuna, Mundulea, Rhynchosia, Sesbania, Smithea, Strongylodon, Vigna, Voandzeia, Zornia [13] and Acacia [16]. A large number of stomata were observed in abaxial surface as compare to adaxial, similar pattern was observed in Centrolobium tomentosum, Erythrina speciosa, E. falcata and Holocalyx balansa [17-20]. In P.tetragonolobus stomata distribution on adaxial (Figure 13A) and abaxial surface (Figure 13B) were amphistomatic type and stomata type was paracytic. All the subsidiary cells were irregular shaped and highly sinuous. In upper epidermis stomatal index range from 5.54-9.27\% and lower epidermis it was 53.57-61.29\%.

Present study reveals that this plant possess some important anatomic characters such as unilacunar node, sac like parenchymatous outgrowth in leaves, cylindrical and arc shaped vascular strands in petiole and paracytic stomata with amphistomatic distribution.

\section{CONCLUSION}

Anatomical and micromorphological (stomata) characteristics might be useful in the definition of this species. Nevertheless, these characteristics will be more valuable if other species of Psophocarpus are also examined.

\section{REFERENCES}

[1] T. Hymowitz, J. Boyd, "Origin, Ethnobotany and Agricultural potential of the winged bean-Psophocarpus tetragonolobus", Economic Botany, Vol.31, pp.180-188, 1977.

[2] O. Smith, J. Ilori, P. Onesirosan, "The proximate composition and nutritive value of the winged bean (Psophocarpus tetragonolobus (L.) DC) for broilers", Animal Feed Science and Technology, Vol.11, pp.231-237, 1984. 
[3] Anon, "The Winged Bean: A high protein crop for the tropics": National Academy of Sciences, Washington DC. U. S. A, pp.1-43, 1975a.

[4] Anon, "Underexploited tropical plants with promising economic value", National Academy of Sciences. Washington DC. U. S. A, pp.56-61, 1975b.

[5] Anon, "The winged bean. A high protein crop for the tropics", National Academy Press, Washington DC, Vol.46, 1981.

[6] G.B. Maesfield, "Psophocarpus tetragonolobus- A crop with a future”. Field Crops, Vol.26, pp.157-176, 1973.

[7] B. Verdcourt, P. Halliday, "A revision of Psophocarpus (Leguminosae-Papilionoideae-Phaseoleae)", Kew Bulletin, Vol. 33, Issue.2, pp.191-227, 1978.

[8] T.N. Khan, "Papua New Guinea: A Centre of genetic diversity in winged bean (Psophocarpus tetragonolobus (L.) DC", Euphytica, Vol.25, pp. 693-706, 1976.

[9] Chandra Sekhar Mohanty, Rama Chandra Pradhan, Vinayak Singh, Neha Singh, Rojalin Pattanayak, Om Prakash, Chandan Singh Chanotiya, Prasant Kumar Rout, "Physicochemical analysis of Psophocarpus tetragonolobus (L.) DC seeds with fatty acids and total lipids compositions", Journal of food science and technology, Vol.52, Issue.6, pp. 3660-3670, 2015.

[10] Shuyi Yang, Aurélie Grall, and Mark A. Chapman, "Origin and diversification of winged bean (Psophocarpus tetragonolobus (L.) DC.), a multipurpose underutilized legume", American Journal of Botany. Vol.105, Issue.5, pp.1-10, 2018.

[11] V. Kamal Kumar, R. Rajalakshmi, "Polyembryony in Psophocarpus tetragonolobus (L.) DC. from Kerala, India”, Current Science, Vol. 114, Issue. 3, pp.426-427, 2018.

[12] E.J. Salisbury, "On the causes and ecological significance of stomatal frequency, with special reference to the woodland flora", Philosophical Transactions of the Royal Society, Vol.216, pp.1-65, 1928.

[13] C.R. Metcalfe, L. Chalk, "Anatomy of the dicotyledons I", Clarendon Press, Oxford, pp.504-516, 1950.

[14] M.B. Marcia da Silva, S.C.O. Asaph Santana, M.M. Rejane Pimentel, C.L. Flavia Silva, P. Karina, Randau, A.L. Luiz Soares, "anatomy of leaf and stem of Erythrina velutina", Brazilian journal of Pharmacognosy, Vol.23, Issue.2, pp.200-206, 2012.

[15] Sara Basconsuelo, Monica Grosso, Mirta Graciela Molina, Rosana Malpassi, Teresa Kraus, Cesar Bianco, "Comparative root anatomy of papilionoid Legumes". Flora. pp. 799-807, 2011.

[16] A.M. Shaheen. "Morphological and cytogenetical variations in the ecological population of Acacia Mill in Egypt", Ph. D. Thesis, South Valley University, Aswan Faculty of Science, Egypt, 1995.

[17] E.E. Almeida, "Pharmacognostic characterization of Erythrina falcate Benth. Fabaceae", Brazilian Journal of Pharmacognosy, Vol.20, pp.100-105, 2010.

[18] E.E. Almeida, "Pharmacological characterization of leaves and barks of the species Erythrina speciosa Andrews", BioFar, Vol.5, pp.34-47, 2011.

[19] M. Erbano, M.R. Duarte, "Centrolobium tomentosum: macro and microscopic diagnosis of the leaf and stem", Brazilian Journal of Pharmacognosy, Vol.22, pp.249-256, 2012.

[20] S.M.S. Lo, M.R. Duarte, "Morpho-anatomical study of the leaf and stem of paualecrim: Holocalyx balansae", Brazilian Journal of Pharmacognosy, Vol.21, pp.4-10, 2011.

\section{AUTHORS PROFILE}

Mr. Kamal Kumar.V is a Research scholar, Department of Botany, University of Kerala, Karyavattom, Kerala, India. He has completed M.Sc. Degree in Botany from Madurai Kamaraj University, Madurai, Tamil Nadu, India and B.Ed Degree in Natural Science from Kerala University, Trivandrum, Kerala, India.

Dr. R. Rajalakshmi is currently working as Assistant Professor, Department of Botany, University of Kerala, Karyavattom, Kerala, India. She has awarded with a Ph.D. Degree in Botany from Mahatma Gandhi University, Kerala, India. The author has published more than 45 research papers in reputed

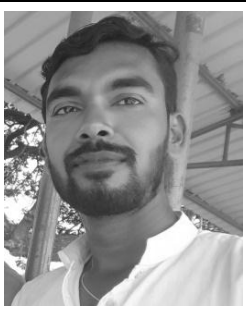
international journals. 